Bangladesh J. Plant Taxon. 18(2): 149-152, 2011 (December)

(C) 2011 Bangladesh Association of Plant Taxonomists

\title{
NEW TAXA OF ELATOSTEMA (URTICACEAE) FROM THAILAND AND INDIA
}

\author{
Hai YAN BI ${ }^{1}$, Zhi Rong Yang AND Qi Lin ${ }^{*}$ \\ State Key Laboratory of Systematic and Evolutionary Botany, Institute of Botany, \\ Chinese Academy of Sciences, Beijing 100093, P. R. China
}

Keywords: Elatostema; E. intanondense; E. ranongense var. glabroum; Urticaceae.

\begin{abstract}
In this study, one new species and one new variety are described and illustrated. Elatostema intanondense Q. Lin (Urticaceae), collected from Doi Intanond of Chiang Mai in Thailand, is morphologically similar to E. subincisum Weddell, but differs by having obscure stipules (vs. conspicuous, linear-lanceolate, 5-6 $\mathrm{mm}$ long in $E$. subincisum), and elliptic to lanceolate nanophylls, 3-7 × 1.5-3.0 mm (vs. absent in E. subincisum). Elatostema ranongense Yahara var. glabroum Q. Lin, a new variety collected from Khasi Hills in Mawhplong of Meghalaya, India. This new variety has glabrous stems and glabrous leaves that differs from var. ranongense that having densely hirtellous stems, densely strigillose leaf blade on abaxial surface along veins.
\end{abstract}

\section{Introduction}

The genus Elatostema J. R. Forster \& G. Forster (Urticaceae) contains approximately 300 species primarily distributed in tropical and subtropical Africa, Asia, and Oceania (Lin et al., 2003). Elatostema is distinguished from the other genera of Urticaceae by having capitula inflorescences with receptacles and involucres. During examination of Asian specimens of Elatostema, a new species and a new variety, Elatostema intanondense Q. Lin and Elatostema ranongense Yahara var. khasiense Q. Lin, were found from Thailand and India, respectively.

\section{Elatostema intanondense Q. Lin sp. nov.}

(Fig. 1)

Diagnosis: Habitu Elatostemati subinciso Weddell valde simile, quod stipulis minimis vel obscuris, foliis abortivis ellipticis vel lanceolatis, 3-7 mm longis, 1.5-3.0 mm latis differt (non stipulis linearilanceolatis, 5-6 mm longis, foliis abortivis absentibus).

Type: Thailand: Chiang Mai: Doi Intanond, 1400-1700 m, 18³0’ N, 98³0’ E, 9 Nov. 1974, K. Larsen \& S. S. Larsen 34423 (Holotype - L; Isotype - L).

Perennial herbs, monoecious, c. $20 \mathrm{~cm}$ tall, glabrous. Stems erect, branched. Leaves alternate; stipules obscure; petiole $0-1 \mathrm{~mm}$ long; leaf blade membranaceous or papery, obliquely oblonglanceolate, $2.0-4.5 \times 1.0-1.5 \mathrm{~cm}$, semitriplinerved, base obliquely cuneate, margin deeply subpinnatifidly crenate or serrate, apex caudate to acuminate. Cystoliths conspicuous, sparse, random; nanophylls elliptic to lanceolate, 3-7 mm long, 1.5-3.0 mm wide. Flowers monoecious,

*Corresponding author. E-mail: linqi@ibcas.ac.cn.

${ }^{1}$ Graduate University of Chinese Academy of Sciences, Beijing 100049, P. R. China. 
capitate. Male inflorescences axillary, solitary, 3-7 mm in diam.; peduncle sessile; receptacle 2-5 $\mathrm{mm}$ in diam.; bracts ovate; bracteoles lanceolate to linear; male flowers 4-merous. Female inflorescences axillary, solitary, 5-8 $\mathrm{mm}$ in diam.; peduncle sessile; receptacle $3.5-6.5 \mathrm{~mm}$ in diam.; bracts broadly ovate; bracteoles spathulate-linear; female 4-merous. Achenes ellipsoidal, c. 6-ribbed.

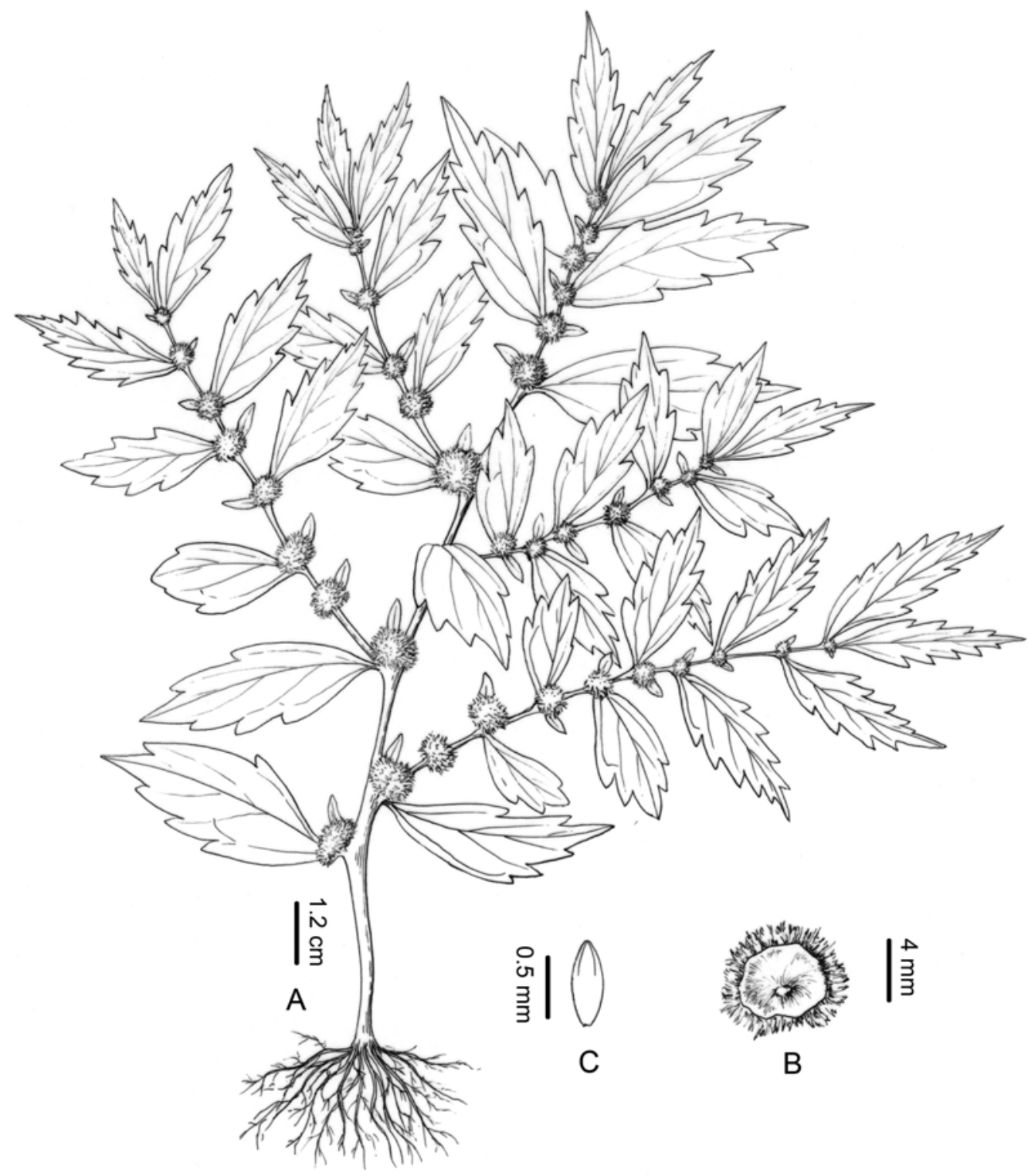

Fig. 1 Elatostema intanondense Q. Lin sp. nov. (from K. Larsen \& S. S. Larsen 34423=L Herb. Bar Code No. 0412346, holotype, L): A. habit; B. female inflorescence (ventral view); C. achene. 
Phenology: Flowering September; fruiting from October to November.

Distribution and habitat: Only known from the type locality in Doi Intanond, Chiang Mai of central Thailand, at altitudes between 1400 and $1700 \mathrm{~m}$ above sea level.

Note: Morphologically, E. intanondense Q. Lin is similar to E. subincisum Weddell that occurring in India and Nepal (Weddell, 1856) based on small herbs, glabrous; stems erect, branched; petiole absent; leaf blade margin deeply subpinnatifidly crenate or serrate, apex caudate to acuminate. More detailed morphological differences between two species are given in Table 1 .

\section{Elatostema ranongense Yahara var. glabroum Q. Lin var. nov.}

(Fig. 2)

var. ranongensi differt caulibus glabribus et foliis glabris.

Type: India. Assam (= Meghalaya): Mawphlng (= Mawhplong), Khasi Hills, 2000 m, 14 September 1949, Rupchand 2281 (Holotype - L). Stems and leaves glabrous.

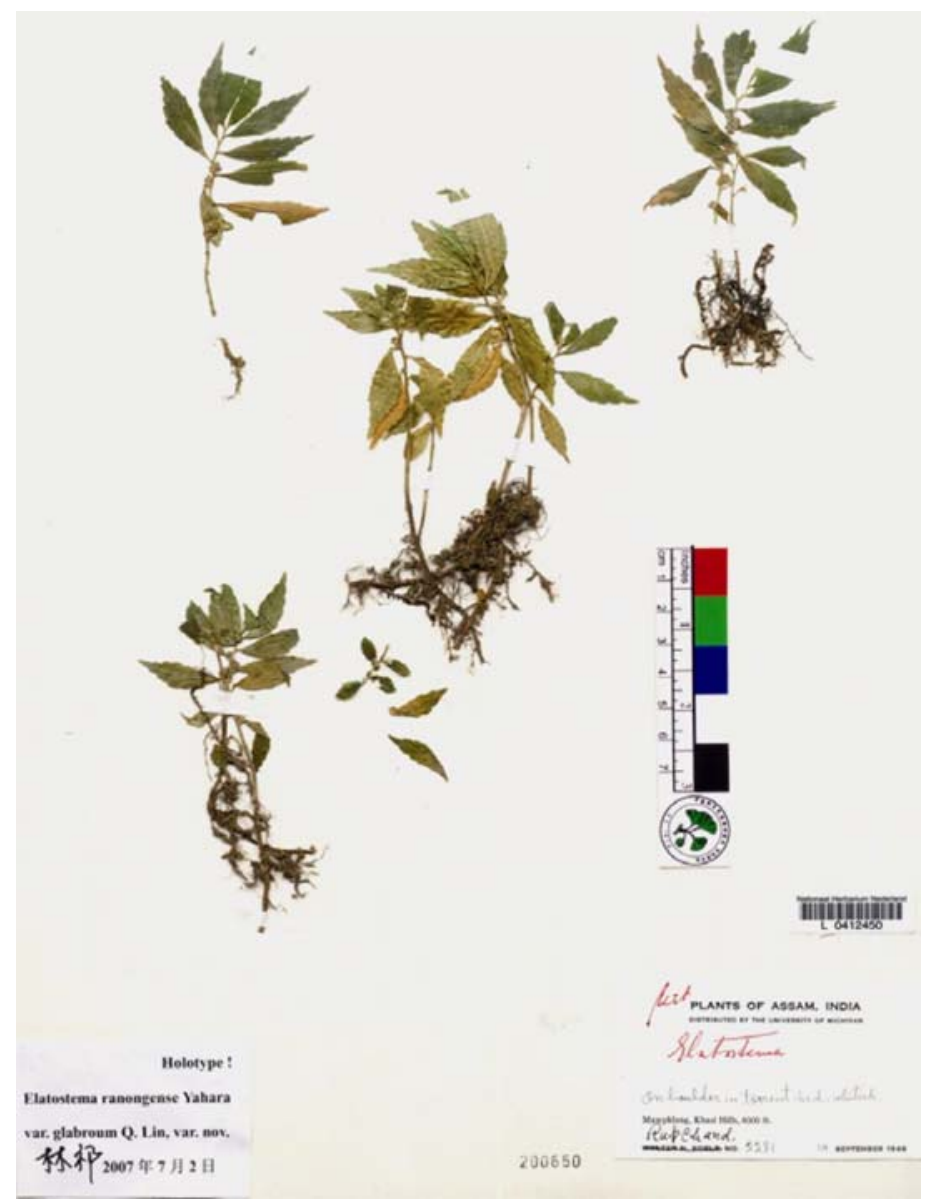

Fig. 2. Holotype of Elatostema ranongense Yahara var. glabroum Q. Lin (from Rupchand 2281, L). Photographed by Q. Lin. 
Phenology: Flowering September; fruiting from October to November.

Distribution and habitat: The new variety is only known from the type locality at Khasi Hills in Mawphlong of Meghalaya, India. It occurs under moist forests at altitude of $2000 \mathrm{~m}$ above sea level.

Table 1. Comparisons of morphological characters between Elatostema intanondense Q. Lin and $E$. subincisum Weddell.

\begin{tabular}{|c|c|c|}
\hline Characters & E. intanondense & E. subincisum \\
\hline Stipules & obscure & conspicuous, linear-lanceolate, 5-6 mm long \\
\hline Leaf blade & $\begin{array}{l}\text { obliquely oblong-lanceolate, } \\
2.0-4.5 \times 1.0-1.5 \mathrm{~cm}\end{array}$ & $\begin{array}{l}\text { obliquely oblong-lanceolate, } 1.5-3.5 \times 0.6- \\
1.2 \mathrm{~cm}\end{array}$ \\
\hline Nanophylls & $\begin{array}{l}\text { present, elliptic to lanceolate, } \\
\times 1.5-3.0 \mathrm{~mm} \text { wide }\end{array}$ & absent \\
\hline $\begin{array}{l}\text { Male } \\
\text { inflorescences }\end{array}$ & $\begin{array}{l}3-7 \mathrm{~mm} \text { in diam.; sessile; receptacle } 2- \\
5 \mathrm{~mm} \text { in diam. }\end{array}$ & $\begin{array}{l}2-5 \mathrm{~mm} \text { in diam.; sessile; receptacle } \\
3 \mathrm{~mm} \text { in diam. }\end{array}$ \\
\hline $\begin{array}{l}\text { Female } \\
\text { inflorescences }\end{array}$ & $\begin{array}{l}5-8 \mathrm{~mm} \text { in diam.; sessile; receptacle } \\
3.5-6.5 \mathrm{~mm} \text { in diam. }\end{array}$ & $\begin{array}{l}3.0-5.5 \mathrm{~mm} \text { in diam.; sessile; receptacle } 1.5- \\
3.0 \mathrm{~mm} \text { in diam. }\end{array}$ \\
\hline
\end{tabular}

The new variety has glabrous stems and glabrous leaves which differs from var. ranongense that having densely hirtellous stems, densely strigillose leaf blade on abaxial surface along veins.

\section{Acknowledgments}

Thanks are due to the curators of herbaria L and TI for the loan of specimens or for permission to examine specimens. This work was supported by Plant Specimen Digitization and Chinese Virtual Herbarium Establishment (grant number 2005DKA21401) and the Project of the Education Department in Hunan Province (11A109).

\section{References}

Lin, Q., Friis, I. and Wilmot-Dear, C.M. 2003. Elatostema (Urticaceae). In: Wu, Z.Y. and Raven, P.H. (eds), Flora of China. Vol. 5. Science Press, Beijing, and Missouri Botanical Garden Press, St. Louis, USA. pp. 127-163.

Weddell, H.A. 1856. Monographie de la Famille des Urticées. Archives du Muséum D’Histoire Naturelle 9: $1-332$. 